\title{
Physico-chemical attributes of a Cambisol under pasture managed with annual burns after sugarcane vinasse application
}

\author{
Thadeu Rodrigues de Melo ${ }^{1} \cdot$ Rogério Resende Martins Ferreira $^{2} \cdot$ Deisi Navroski $^{1}$ (1) \\ Clarissa Tieme Matsuda Feltran' ${ }^{1}$ João Tavares Filho'
}

Received: 6 September 2017 / Accepted: 6 January 2018 / Published online: 17 January 2018

(c) The Author(s) 2018. This article is an open access publication

\begin{abstract}
Purpose Sugarcane vinasse is generated in large amounts and can be utilized to improve soil attributes, especially in areas degraded by burns. The aim of the present study was to evaluate the effects of sugarcane vinasse on physico-chemical attributes of a Cambisol managed via annual burns.

Methods Soil samples were collected from an annually burned area under pasture and used in an experiment in pots to evaluate the effects of dosages of vinasse $\left(0,18.8,37.5,56.3,75.0,112.5\right.$, and $\left.150.0 \mathrm{~m}^{3} \mathrm{ha}^{-1}\right)$ on water-dispersible clay, $\mathrm{pH}_{\mathrm{H}_{2} \mathrm{O}}$, organic matter, $\mathrm{K}^{+}, \mathrm{Ca}^{2+}+\mathrm{Mg}^{2+}$, and $\mathrm{K}^{+} /\left(\mathrm{Ca}^{2+}+\mathrm{Mg}^{2+}\right)$.

Results The results showed that vinasse application reduces water-dispersible clay, does not alter $\mathrm{pH}_{\mathrm{H}_{2} \mathrm{O}}$, and increases organic matter, $\mathrm{K}^{+}, \mathrm{Ca}^{2+}+\mathrm{Mg}^{2+}$, and $\mathrm{K}^{+} /\left(\mathrm{Ca}^{2+}+\mathrm{Mg}^{2+}\right)$. The water-dispersible clay was reduced by the formation of bonds with organic matter, which overlapped the repulsive forces intensified by the increment of $\mathrm{K}^{+} /\left(\mathrm{Ca}^{2+}+\mathrm{Mg}^{2+}\right)$. The estimated vinasse dosage that provided the minimum water-dispersible clay $\left(69 \mathrm{~g} \mathrm{~kg}^{-1}\right)$ was $110 \mathrm{~m}^{3} \mathrm{ha}^{-1}$.

Conclusions Vinasse can be applied to improve the physico-chemical attributes of soils degraded by annual burns.
\end{abstract}

Keyword Organic fertilization $\cdot$ Soil flocculation $\cdot$ Sustainability $\cdot$ Soil restoration

\section{Introduction}

The microregion of São João Del Rei, in the State of Minas Gerais, is characterized by the predominance of small rural properties, mainly used for dairy cattle. For feeding of the animals, pastures of low productivity are used, which implies in the necessity of supplementation, commonly carried out by the cultivation of sugarcane (Pelegrini 2010).

The pastures are burned mainly during the dry period, between June and August, to clear areas, burn residues, control shrub growth, reduce the incidence of invasive plants, and eliminate pests and diseases (Horta et al. 2009).

Deisi Navroski

deisinavroski@gmail.com

1 Department of Agronomy, Universidade Estadual de Londrina [State University of Londrina] (UEL), Celso Garcia Cid Highway, s/n, 10011, CEP 86057-970 Londrina, PR, Brazil

2 Empresa Brasileira de Pesquisa Agropecuária [Brazilian Agricultural Research Corporation], EMBRAPA, Rio Branco, AC, Brazil
However, this practice reduces the organic matter content and, consequently, leads to soil degradation (Ferreira et al. 2012).

The sugarcane is also used in the artisanal manufacture of sugarcane spirit, with vinasse being the main residue generated during ethanol distillation; For each ton of sugarcane processed, $780 \mathrm{~L}$ of vinasse are generated (Sebrae 2001). Applying sugarcane vinasse to the soil can help attenuate soil degradation and improve vegetal development (Canellas et al. 2003).

Recently, there have been many discussions on the progress of wastewater reuse globally to protect the environment and achieve sustainable resources (Wu et al. 2013). Vinasse can be reused as a fertilizer, providing nutrients to plants, mainly potassium, nitrogen, and phosphorous (Moraes et al. 2015; Dotaniya et al. 2016). An understanding of the effects of vinasse on soil physico-chemical attributes is valuable, especially in degraded areas, to maximize the efficiency of soil restoration and increase family income.

The high levels of potassium in vinasse and other sugarcane residues (Kumar and Chopra 2016) can increase waterdispersible clay and cause physical degradation due to the 
increments in electrostatic repulsion between the clays (Marchuk and Rengasamy 2011). However, organic matter can favor the flocculation and aggregation of clays, thus improving soil structural stability (Bronick and Lal 2005). Therefore, the predominance of clay dispersion or flocculation will depend on the capacity of one of these two processes to overlap the other.

The hypothesis of the present study is that vinasse will change the content of water-dispersible clay, depending on the chemical changes resulting from the formation of bonds by organic molecules and the electrostatic repulsion by $\mathrm{K}^{+}$ increment. The aim of the present study was to evaluate the effects of sugarcane vinasse on physico-chemical attributes of a Cambisol managed with annual burns.

\section{Materials and methods}

\section{Site and soil characterization}

This study was performed in pots containing soil from pastures located in the hydrographic basin of Alto Rio Grande, municipality of Nazareno, Minas Gerais, Brazil, located at $21^{\circ} 22^{\prime} \mathrm{S}$ and $44^{\circ} 61^{\prime} \mathrm{W}$ with an average elevation of $935 \mathrm{~m}$ (Fig. 1). The regional climate is high-elevation tropical, with cold, dry winters and hot, humid summers, and is classified as Cwa in the Köppen system. The average annual temperature ranges from 18 to $19{ }^{\circ} \mathrm{C}$, and the total annual rainfall ranges from 1200 to $1500 \mathrm{~mm}$.

The soil is classified as a Cambisol based on the International Soil Classification System (IUSS Working Group 2015) (Brazilian classification: Cambissolo Háplico; US Department of Agriculture classification: Inceptisol), and originates from pelitic rocks and quartzite (Horta et al. 2009), under native pasture (Diandrostachya chrysotrix,
Paspalum plicatulum, and Andropogon leucostachys). The soil was managed using annual burns to clear vegetation.

A total of 40 soil samples were collected 30 days after the annual burn from a depth of $0-20 \mathrm{~cm}$. In the laboratory, the samples were mixed and sieved $(2 \mathrm{~mm})$. The soil physico-chemical attributes were determined (Table 1), and the experimental pots were filled.

Table 1 Physico-chemical attributes of the Cambisol under pasture managed with annual burns collected at a depth of $0-20 \mathrm{~cm}$

\begin{tabular}{ll}
\hline Attribute & Value \\
\hline Clay $\left(\mathrm{g} \mathrm{kg}^{-1}\right)^{\mathrm{a}}$ & 380 \\
$\mathrm{Silt}\left(\mathrm{g} \mathrm{kg}^{-1}\right)^{\mathrm{a}}$ & 250 \\
Sand $\left(\mathrm{g} \mathrm{kg}^{-1}\right)^{\mathrm{a}}$ & 370 \\
Silt/clay & 0.67 \\
Water-dispersible clay $\left(\mathrm{g} \mathrm{kg}^{-1}\right)^{\mathrm{b}}$ & 91.0 \\
Particle density $\left(\mathrm{Mg} \mathrm{m}^{-3}\right)^{\mathrm{c}}$ & 2.67 \\
$\mathrm{pH}_{\mathrm{H}_{2} \mathrm{O}}{ }^{\mathrm{d}}$ & 4.5 \\
$\mathrm{CEC}_{\mathrm{pH}}\left(\mathrm{cmol}_{\mathrm{c}} \mathrm{dm}^{-3}\right)^{\mathrm{e}}$ & 6.5 \\
$\mathrm{Ca}^{2+}+\mathrm{Mg}^{2+}\left(\mathrm{cmol}_{\mathrm{c}} \mathrm{dm}^{-3}\right)^{\mathrm{e}}$ & 0.83 \\
$\mathrm{~K}^{+}\left(\mathrm{cmol}_{\mathrm{c}} \mathrm{dm}^{-3}\right)^{\mathrm{e}}$ & 0.006 \\
${\text { Organic matter }\left(\mathrm{g} \mathrm{kg}^{-1}\right)^{\mathrm{f}}}$ & 8.0 \\
\hline
\end{tabular}

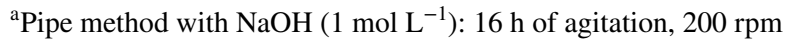

${ }^{\mathrm{b}}$ Pipe method without dispersant: $3 \mathrm{~h}$ of agitation, $30 \mathrm{rpm}$

${ }^{\mathrm{c}}$ Determined by the volumetric balloon with ethanol method

${ }^{\mathrm{d}} 1: 2.5$ soil:water ratio (v:v)

${ }^{\mathrm{e}} C E C$ cation exchange capacity $\left(\mathrm{H}+\mathrm{Al}^{3+}+\mathrm{Ca}^{2+}+\mathrm{Mg}^{2+}+\mathrm{K}^{+}\right)$. $\mathrm{H}+\mathrm{Al}^{3+}$ determined by potentiometry after equilibrium with SMP solution. $\mathrm{Ca}^{2+}+\mathrm{Mg}^{2+}$ determined after exchange with $\mathrm{KCl}$ $\left(1 \mathrm{~mol} \mathrm{~L}^{-1}\right) . \mathrm{K}^{+}$extracted by Mehlich-1

${ }^{\mathrm{f}}$ Oxidation with $\mathrm{K}_{2} \mathrm{Cr}_{2} \mathrm{O}_{7}$ in sulfuric medium
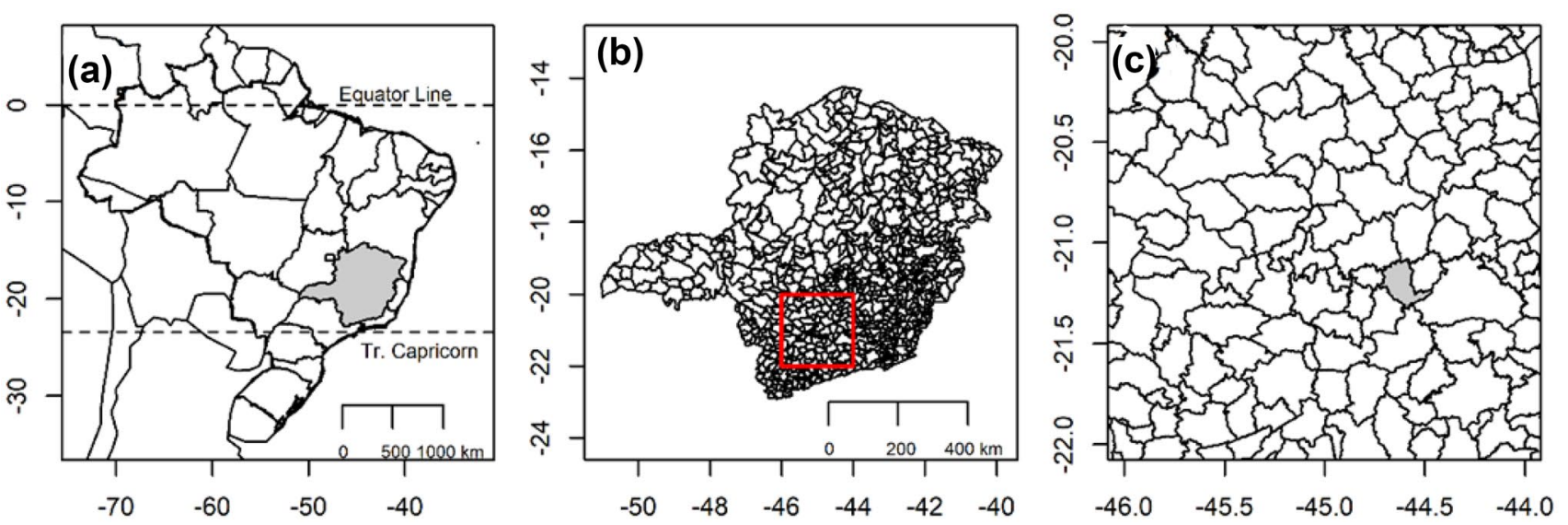

Fig. 1 Location of Minas Gerais State, Brazil (a), detail of Minas Gerais' municipalities (b) and Nazareno municipality (c) 


\section{Establishment and conduction of the experiment}

The pots had inner linings composed of plastic bags, and were filled with $2.0 \mathrm{~kg}$ of $2 \mathrm{~mm}$ sieved soil from the composite sample (composed of a mix of the 40 discrete samples collected in the area). A fully randomized experimental design was used, with seven treatments and three replications. The treatments consisted of different dosages of vinasse [0 (control) $18.8,37.5,56.3,75.0,112.5$, and $\left.150.0 \mathrm{~m}^{3} \mathrm{ha}^{-1}\right]$. The characterization of the vinasse is shown in Table 2. After vinasse application, the soil was watered to maximum retention capacity and incubated, leaving an opening for gaseous exchange during the 60-day incubation period.

The maximum water retention capacity was determined by the filling of volumetric rings with soil with subsequent saturation and gravitational drainage until constant weight. After incubation, the pots were opened and three replicates were collected per treatment.

The $\mathrm{pH}_{\mathrm{H}_{2} \mathrm{O}}$ and exchangeable $\mathrm{K}^{+}$and $\mathrm{Ca}^{2+}+\mathrm{Mg}^{2+}$, organic matter and water-dispersible clay were determined according to the method of Embrapa (1997) and Pavan et al. (1992). The $\mathrm{pH}$ was measured in a 1:2.5 soil:water ratio (v:v), $\mathrm{K}^{+}$was measured after extraction with Mehlich-1 and quantified in a flame spectrophotometer, and $\mathrm{Ca}^{2+}+\mathrm{Mg}^{2+}$ were exchanged by $\mathrm{KCl} 1 \mathrm{~mol} \mathrm{~L}^{-1}$ and quantified by titration with EDTA- $\mathrm{Na}_{2}$. Organic carbon was determined by oxidation with $\mathrm{K}_{2} \mathrm{Cr}_{2} \mathrm{O}_{7}$ in sulfuric medium and multiplied by the Van Bemmelen factor of 1.724 to obtain the organic matter content. The water-dispersible clay was evaluated with the pipette method, based on Stoke's Law, on samples agitated

Table 2 Characterization of the vinasse used in the present study using a laboratory orbital stirring table (Tecnal TE-145) at $30 \mathrm{rpm}$ for $3 \mathrm{~h}$.

\section{Statistical analyses}

The ANOVA's assumptions of normality and homoscedasticity were tested using the Shapiro-Wilk and Cochran's tests, respectively. The results were evaluated by ANOVA ( $F$ test), and for low $p$ values $(\leq 0.05)$, the best regression model was adjusted. The relationship between chemical attributes and water-dispersible clay was determined with linear regression models. The $\mathrm{R}$ software ( $\mathrm{R}$ version 3.3.2) was used for data analysis and creation of figures.

\section{Results and discussion}

The effects of vinasse on soil chemical attributes are shown in Fig. 2.

None of the applied doses exceeds the critical K content in the soil, which is $5 \%$ of the $\mathrm{CEC}_{\mathrm{pH} 7}$ plus the annual extraction of the plants, delimited in the Normative Deliberation of the State Council of Minas Gerais (Minas Gerais 2011), since at the highest dose, soil presented only $0.5 \%$ of saturation per K (data not shown).

The $\mathrm{pH}$ strongly affects water-dispersible clay and, consequently, soil structural stability. Changes in $\mathrm{pH}$ can increase the net charge of the clay surface and intensify the repulsive forces, favoring dispersion (Plaza et al. 2015). However, in the present study, vinasse application did not affect soil pH (Fig. 2a), despite changes in this attribute having been reported previously (Silva and Ribeiro 1998; Ribeiro et al. 2012).

The increment in $\mathrm{pH}$ by the vinasse application is associated to the higher biochemical demand for oxygen, which makes the $\mathrm{H}^{+}$the final acceptor of electrons, raising the $\mathrm{pH}$ (Moran-Salazar et al. 2016), even with the low $\mathrm{pH}$ of the vinasse (Ribeiro et al. 2012). As the $\mathrm{pH}$ increment is dependent on biological activity, the continuous use of fire for pasture management may have reduced the microbial population, preventing $\mathrm{pH}$ changes.

The soil organic matter increased linearly with vinasse application (Fig. 2b), corroborating the study of Canellas et al. (2003), that reported an increase in the humic and fulvic acids in an Inceptisol caused by vinasse addition during a long period.

Organic molecules can disperse or flocculate soil clays. Some organic compounds such as proteins (Nelson et al. 1999) and low molecular weight organic compounds (Nguyen et al. 2013) can act as clay dispersants. However, organic molecules, such as the aliphatic ones (Nelson et al. 1999), can also bind two or more clays together, which increases aggregate stability (Bronick and Lal 2005) 

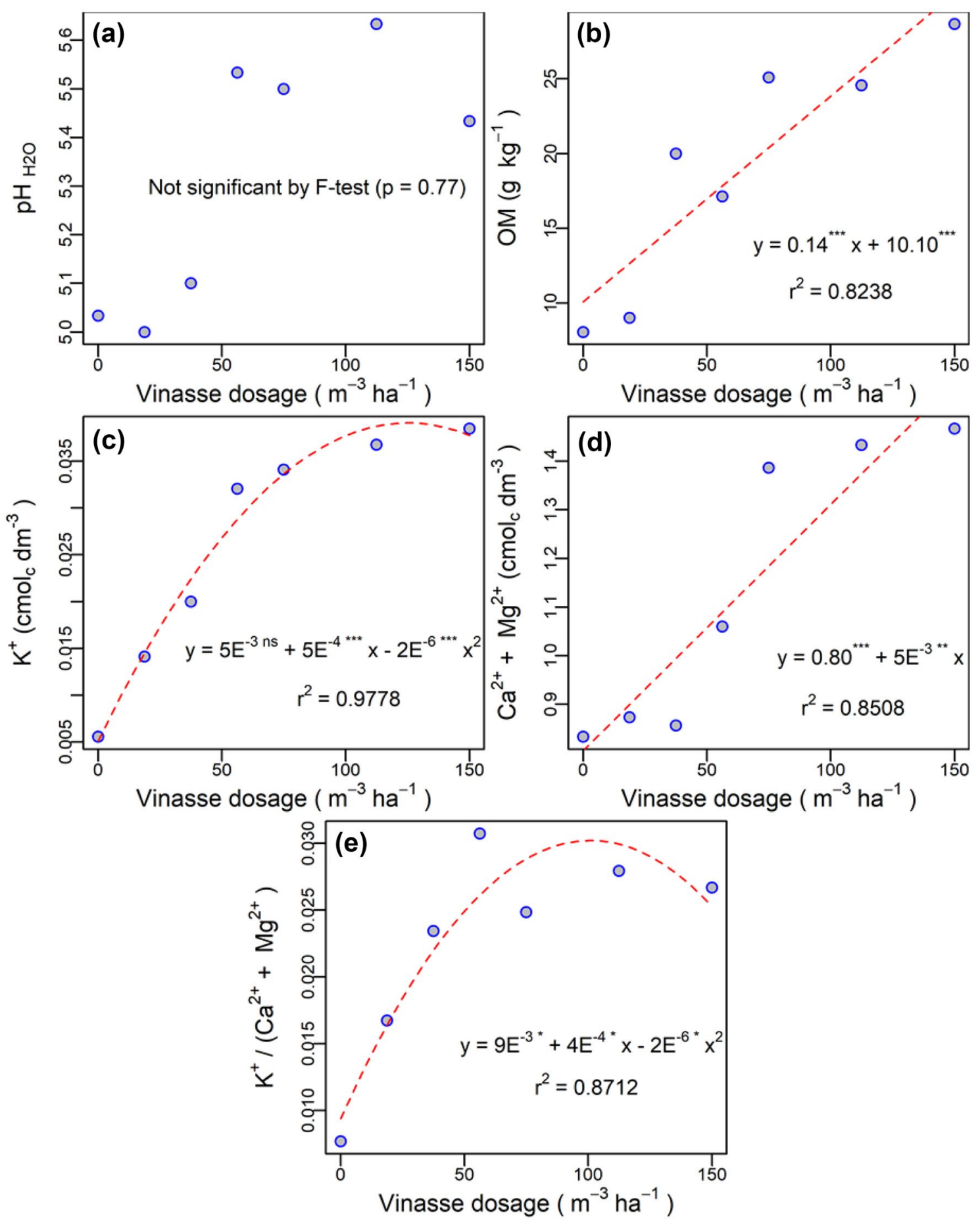

Fig. 2 Results from $F$ test and regression model for the evaluated attributes in a Cambisol fertilized with vinasse

and clay flocculation (Tavares Filho et al. 2014). In addition, vinasse increases microbiological activity, which can release exudates and increase soil aggregation (Bronick and Lal 2005). The increment in total soil organic matter content following vinasse application linearly reduced the water-dispersible clay (Fig. 3a).
In electronegative soils, monovalent cations increase the water-dispersible clay, while bivalent cations favor flocculation (Melo et al. 2016). Vinasse dosages increased $\mathrm{K}^{+}$, $\mathrm{Ca}^{2+}+\mathrm{Mg}^{2+}$, and $\mathrm{K}^{+} /\left(\mathrm{Ca}^{2+}+\mathrm{Mg}^{2+}\right)$ values (Fig. $2 \mathrm{c}-\mathrm{e}$ ). It is expected that samples with greater values of $\mathrm{K}^{+} /$ $\left(\mathrm{Ca}^{2+}+\mathrm{Mg}^{2+}\right)$ become more dispersed than those with 

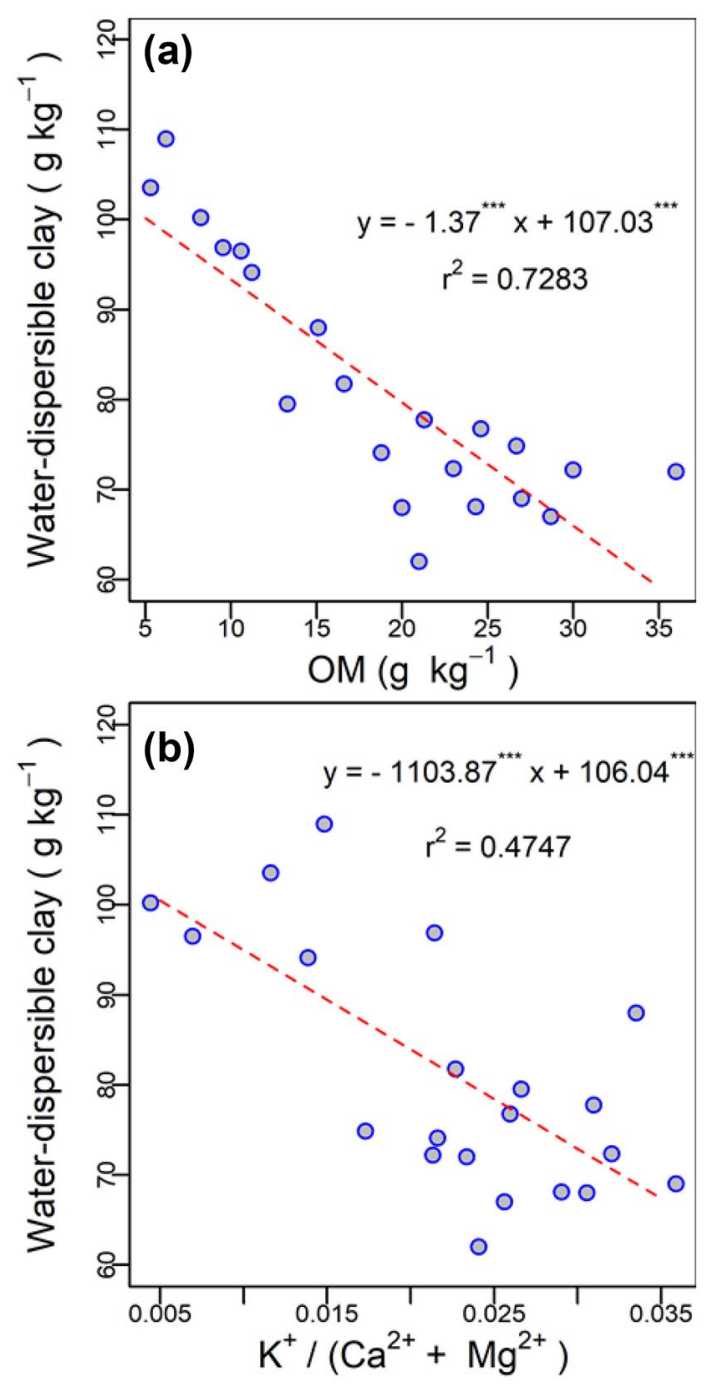

Fig. 3 Relationship between water-dispersible clay and total soil organic matter content (a) and the ratio of monovalent/bivalent cations (b) in a Cambisol fertilized with vinasse

lesser values. Dispersion is intensified in soils with higher monovalent cation concentration due to thickening of the electric double layer (Mahanta et al. 2012), smaller zeta potential neutralization when compared to bivalent cations (Marchuk and Rengasamy 2011), and smaller interaction with soil organic molecules (Setia et al. 2013), which reduces the clay-organic matter bonds (Roychand and Marschner 2014).

A negative linear correlation was obtained between $\mathrm{K}^{+}$/ $\left(\mathrm{Ca}^{2+}+\mathrm{Mg}^{2+}\right)$ and water-dispersible clay, which was in contrast to our expectations (Fig. 3b). The statistical significance of this model (Fig. 3b) is probably owing to the correlation between $\mathrm{K}^{+} /\left(\mathrm{Ca}^{2+}+\mathrm{Mg}^{2+}\right)$ and organic matter when vinasse is applied, with the flocculent effects caused by clay-organic matter binding overlapping the electrostatic repulsive forces caused by the increment in $\mathrm{K}^{+} /\left(\mathrm{Ca}^{2+}+\mathrm{Mg}^{2+}\right)$ (Fig. 4).

Prado et al. (2014) reported a reduction in water-dispersible clay in an Oxisol, with organic matter and $\mathrm{K}^{+}$increment, corroborating the results of the present study.

The remarkable presence of aluminum sesquioxides in this Cambisol (Horta et al. 2009) and its strong interaction with organic compounds (Heckman et al. 2011) explains the association of these clay-sized minerals to organic vinasse compounds reducing water-dispersible clays.

Some studies reported in the literature corroborates the idea that the effects of organic compounds after vinasse application overlap the repulsion caused by $\mathrm{K}^{+}$increments in the soil exchange complex. Ribeiro et al. (2013) observed that vinasse application increased the amount of energy necessary to disperse the aggregates by reducing the disaggregation and dispersion constants in an Oxisol and an Ultisol. Vicente et al. (2012) observed a significant correlation between total organic carbon and aggregation indices in different soils when vinasse was added. So, vinasse can be applied to improve the physico-chemical attributes of soils degraded by annual burns.

The model from the data in Fig. 5 estimates that the minimum clay dispersion $\left(69 \mathrm{~g} \mathrm{~kg}^{-1}\right)$ occurs when $110 \mathrm{~m}^{3} \mathrm{ha}^{-1}$ vinasse is applied. Although the second-degree model fits better, there was no indication of dosages greater than $110 \mathrm{~m}^{3} \mathrm{ha}^{-1}$ increasing dispersion. The absence of response after this dose probably occurred due to the saturation of part of the dispersed clay fraction with phosphate and organic molecules of low molecular weight, which intensify the electronegative potential of the particles, without allowing the formation of bonds and consequently their flocculation (Nguyen et al. 2013).

As the dispersed clay content is extremely dependent on the method used, the interpretation of the suitability for the results is difficult. However, it is known that the closer to
Fig. 4 Organogram of the attributes altered by vinasse application and their effect on the net water-dispersible clay decrease

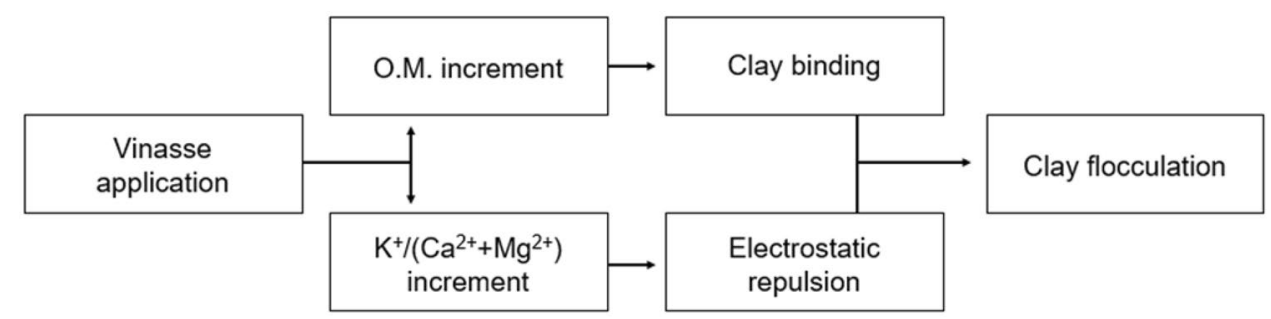




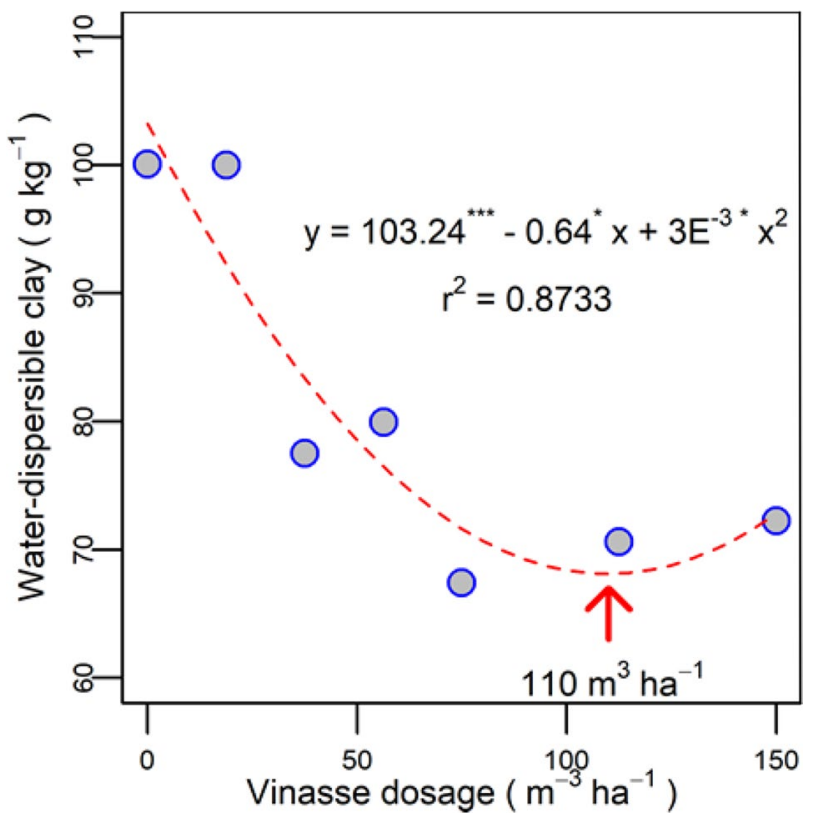

Fig. 5 Water-dispersible clay in function of the applied vinasse dosage

zero, the lower the transport potential and the loss of particles of the clay fraction. With the reduction of clay dispersion, it is expected a lower potential transport of contaminants associated with these particles to water bodies (Martin et al. 2016). In addition, soil structural improvement may occur due to less clogging of pores by the reorganization of the dispersed clay (Spera et al. 2008).

\section{Conclusion}

Our results showed that the vinasse can attenuate the chemical and physical degradation imposed by the management of pastures with fire. Increment on cations concentration $\left(\mathrm{K}^{+}\right.$ and $\mathrm{Ca}^{2+}+\mathrm{Mg}^{2+}$ ) could be observed, suggesting a higher availability to plants. However, the $\mathrm{pH}$ of the soil, initially at 4.5 , could not be neutralized with the vinasse application, probably due to the low biological activity caused by the constant use of fire. Initially, we believed that increasing the $\mathrm{K}^{+} /\left(\mathrm{Ca}^{2+}+\mathrm{Mg}^{2+}\right)$ ratio by the vinasse application could induce the increase of water-dispersible clay content, but the formation of bonds by organic molecules overlapped the $\mathrm{K}^{+}$ dispersive effect, reducing the contents of water-dispersible clay up to the estimated dose of $110 \mathrm{~m}^{3} \mathrm{ha}^{-1}$, from which changes could not be observed. With this change, we expect that the loss of soil particles by the action of rain and its consequent transport to water bodies will be reduced, as well as the clogging of pores in the soil by the reorganization of the dispersed clay. Therefore, vinasse can be applied to improve the physico-chemical attributes of soils degraded by annual burns.

Acknowledgements We acknowledge the National Council for the Improvement of Higher Education-CAPES and the National Council for Scientific and Technological Development-CNPq for granting the productivity, $\mathrm{PhD}$ and masters scholarship to the authors.

\section{Compliance with ethical standards}

Conflict of interest The authors declare that there are no conflicts of interest associated with this study.

Open Access This article is distributed under the terms of the Creative Commons Attribution 4.0 International License (http://creativecomm ons.org/licenses/by/4.0/), which permits unrestricted use, distribution, and reproduction in any medium, provided you give appropriate credit to the original author(s) and the source, provide a link to the Creative Commons license, and indicate if changes were made.

\section{References}

Bronick CJ, Lal R (2005) Soil structure and management: a review. Geoderma 124:3-22. https://doi.org/10.1016/j.geoderma.2004 .03 .005

Canellas LP, Velloso ACX, Marciano CR, Ramalho JFGP, Rumjanek VM, Rezende CE, Santos GA (2003) Chemical soil properties of an Inceptisol under long-term sugarcane crops with vinasse application and without slash burning. Rev Bras Ciênc Solo 27:935-944. https://doi.org/10.1590/S0100-06832003000500018

Dotaniya ML, Datta SC, Biswas DR, Dotaniya CK, Meena BL, Rajendiran S, Regar KL, Lata M (2016) Use of sugarcane industrial by-products for improving sugarcane productivity and soil health. Int J Recycl Org Waste Agric 5:185-194. https://doi. org/10.1007/s40093-016-0132-8

EMBRAPA (1997) Empresa Brasileira de Pesquisa Agropecuária. Manual de métodos de análise de solo, Embrapa, Rio de Janeiro

Ferreira RRM, Maciel BV, Lemes AISBC, Melo TR, Tavares Filho J (2012) Soil quality in areas of inceptisol with different grassland management. Semin-cienc Agrar 33:3069-3074. https://doi. org/10.5433/1679-0359.2012v33n6Supl2p3069

Heckman K, Vazquez-Ortega A, Gao X, Chorover J, Rasmussen C (2011) Changes in water extractable organic matter during incubation of forest floor material in the presence of quartz, goethite and gibbsite surfaces. Geochim Cosmochim Acta 75:4295-4309. http s://doi.org/10.1016/j.gca.2011.05.009

Horta IM, Pereira JA, Marques JJ, Carvalho LMT (2009) Levantamento de reconhecimento com apoio digital dos solos do município de Nazareno-MG. Ciênc Agrotec 33:1940-1947. https://doi. org/10.1590/S1413-70542009000700042

IUSS Working Group WRB (2015) World Reference Base for Soil Resources 2014, update 2015. International soil classification system for naming soils and creating legends for soil maps. FAO, Rome. http://www.fao.org. Accessed 30 may 2017

Kumar V, Chopra AK (2016) Effects of sugarcane pressmud on agronomical characteristics of hybrid cultivar of eggplant (Solanum melongena L.) under field conditions. Int J Recycl Org Waste Agric 5:149-162. https://doi.org/10.1007/s40093-016-0125-7

Mahanta KK, Mishra GC, Kansal ML (2012) Estimation of electric double layer thickness from linearized and nonlinear solutions of 
Poisson-Boltzman equation for single type of ions. Appl Clay Sci 59:1-7. https://doi.org/10.1016/j.clay.2012.02.014

Marchuk A, Rengasamy P (2011) Clay behavior in suspensions is related to the iconicity of clay-cation bonds. Appl Clay Sci 53:754-759. https://doi.org/10.1016/j.clay.2011.05.019

Martin M, Stanchi S, Hossain KMJ, Huq SMI, Barberis E (2016) Potential phosphorus and arsenic mobilization from Bangladesh soils by particle dispersion. Sci Total Environ 536:973-980. http s://doi.org/10.1016/j.scitotenv.2015.06.008

Melo TR, Telles TS, Machado WS, Tavares Filho J (2016) Factors affecting clay dispersion in oxisols treated with vinasse. SeminCienc Agrar 37:3997-4004. https://doi.org/10.5433/1679-0359 .2016v37n6p3997

Minas Gerais (2011) Deliberação Normativa COPAM n 164, de 30 de março de 2011. Diário do Executivo de Minas Gerais. http://www. siam.mg.gov.br/sla/download.pdf?idNorma=16794. Accessed 11 June 2017

Moraes BS, Zaiat M, Bonomi A (2015) Anaerobic digestion of vinasse from sugarcane ethanol production in Brazil: challenges and perspectives. Renew Sustain Energy Rev 44:888-903. https://doi. org/10.1016/j.rser.2015.01.023

Moran-Salazar RG, Sanchez-Lizarraga AL, Rodriguez-Campos J, Davila-Vazquez G, Marino-Marmolejo EN, Dendooven L, Contreras-Ramos SM (2016) Utilization of vinasses as soil amendment: consequences and perspectives. SpringerPlus 5:1007. https://doi. org/10.1186/s40064-016-2410-3

Nelson PN, Baldock JÁ, Clarke P, Oades JM, Curchman GJ (1999) Dispersed clay and organic matter in soil: their nature and associations. Aust J Soil Res 37:289-315. https://doi.org/10.1071/SR98 076

Nguyen MN, Dultz S, Tran TTT, Bui ATK (2013) Effect of anions on dispersion of a kaolinitic soil clay: a combined study of dynamic light scattering and test tube experiments. Geoderma 209210:209-213. https://doi.org/10.1016/j.geoderma.2013.06.024

Pavan MA, Bloch MF, Zempulski HC, Miyazawa M, Zocoler DC (1992) Manual de análise química de solo e controle de qualidade. IAPAR, Londrina

Pelegrini DF (2010) Diagnóstico rural da microrregião de São João del-Rei, vol 48. EPAMIG, Belo Horizonte

Plaza I, Ontiveros-Ortega A, Calero J, Aranda V (2015) Implication of zeta potential and surface free energy in the description of agricultural soil quality: effect of different cations and humic acids on degraded soils. Soil Tillage Res 146:148-158. https:// doi.org/10.1016/j.still.2014.10.013

Prado EAF, Vitorino ACT, Oliveira WH, Espindola DLP, Arantes HP (2014) Dispersion index of aggregates in a Rhodic Ferrasol cultivated with cane under stillage application. Semin-Cienc Agrar 35:2347-2356. https://doi.org/10.5433/1679-0359.2014v35n4Sup $1 \mathrm{p} 2347$
Ribeiro BT, Lima JM, Curi N, Oliveira GC (2012) Electrochemical attributes of soils influenced by sugarcane vinasse. Biosci J 28:25-32

Ribeiro BT, Lima JM, Curi N, Oliveira GC (2013) Aggregate breakdown and dispersion of soil samples amended with sugarcane vinasse. Sci Agric 70:435-441. https://doi.org/10.1590/S010 3-90162013000600009

Roychand P, Marschner P (2014) Respiration and sorption of waterextractable organic carbon as affected by addition of $\mathrm{Ca}^{2+}$, isolated clay or clay-rich subsoil to sand. Pedosphere 24:98-106. https:// doi.org/10.1016/S1002-0160(13)60084-3

Sebrae (2001) Serviço Brasileiro de Apoio às Micro e Pequenas Empresas, Recomendações de controle ambiental para produção de cachaça. SEBRAE, Vitória

Setia R, Rengasamy P, Marschner P (2013) Effect of exchangeable cation concentration on sorption and desorption of dissolved organic carbon in saline soils. Sci Total Environ 465:226-232. https://doi. org/10.1016/j.scitotenv.2013.01.010

Silva AJN, Ribeiro MR (1998) Characterization of xanthic ferralsol under continuous sugarcane cropping in Alagoas State, Brazil: chemical attributes. Rev Bras Ciênc Solo 22:291-299. https://doi. org/10.1590/S0100-06831998000200015

Spera ST, Denardin JE, Escosteguy PAV, Santos HP, Figueroa EA (2008) Dispersão de argila em microagregados de solo incubado com calcário. Rev Bras Ciênc Solo 32:2613-2620. https://doi. org/10.1590/S0100-06832008000700002

Tavares Filho J, Melo TR, Machado W, Maciel BV (2014) Structural changes and degradation of Red Latosols under different management systems for 20 years. Rev Bras Ciênc Solo 38:1293-1303. https://doi.org/10.1590/S0100-06832014000400025

Vicente TFS, Pedrosa EMR, Rolim MM, Oliveira VS, Oliveira AKS, Souza AMPL (2012) Soil attributes and soil aggregate stability relationship in sugarcane fields with and without vinasse application. Rev Bras Eng Agríc Ambient 16:1215-1222. https://doi. org/10.1590/S1415-43662012001100010

Wu TY, Mohammad AW, Lim SL, Lim PN, Hay JXW (2013) Recent advances in the reuse of wastewaters for promoting sustainable development. In: Sharma SK, Sanghi R (eds) Wastewater reuse and management. Springer, Netherlands, pp 47-103. https://doi. org/10.1007/978-94-007-4942-9_3

Publisher's Note Springer Nature remains neutral with regard to urisdictional claims in published maps and institutional affiliations. 